\author{
Przemysław Sołga \\ (Pedagogical University of Krakow, Poland) \\ https://orcid.org/0000-0002-0670-8857 \\ E-mail: przemyslaw.solga@gmail.com
}

\title{
Kościół dla ubogich. Kilka uwag na temat książki Matteo Compagnaro, Posoborowa teologia Ameryki Łacińskiej Geneza, charakterystyka, perspektywy, Papieski Wydział Teologiczny we Wrocławiu, Wrocław 2020, ss. 135
}

The Church for the Poor. Remarks About the Book of Matteo Compagnaro, Posoborowa teologia Ameryki Łacińskiej. Geneza, charakterystyka, perspektywy, Papieski Wydział Teologiczny we Wrocławiu, Wrocław 2020, pp. 135

\section{ABSTRACT}

The article concerns the book of Matteo Compagnaro dedicated to post-conciliar theology in Latin America. The reason for writing the text was many controversial statements of the author of the book. The article evaluates the structure, sources, and factual contents of the monograph by Matteo Compagnaro. The author notes important shortcomings of the work and takes issue with several claims made in the book.

Key words: Catholic Church, Latin America, liberation theology, capitalism

\begin{tabular}{|l|l|l|l|}
\hline \multicolumn{2}{|l|}{ PUBLICATION INFO } \\
\hline
\end{tabular}




\section{STRESZCZENIE}

Artykuł dotyczy książki Matteo Compagnaro poświęconej posoborowej teologii w Ameryce Łacińskiej. Motywem do napisania niniejszego tekstu było wiele kontrowersyjnych stwierdzeń autora opiniowanej książki. W artykule oceniono publikację Matteo Compagnaro, biorąc pod uwagę takie aspekty, jak jej konstrukcja, podstawa źródłowa i zawartość merytoryczna. Zwrócono uwagę na istotne braki w pracy oraz podjętego polemikę z niektórymi stwierdzeniami autora książki.

Słowa kluczowe: Kościół katolicki, Ameryka Łacińska, teologia wyzwolenia, kapitalizm

Ksiądz Matteo Campagnaro to włoski duchowny mieszkający od 2001 r. na stałe w Polsce. W latach 2010-2012 pracował jako wikariusz w parafii NMP Matki Kościoła w Warszawie. Od 2012 r. jest sekretarzem i kapelanem Arcybiskupa Metropolity Warszawskiego kard. Kazimierza Nycza i pierwszym w historii sekretarzem-obcokrajowcem polskiego biskupa. W 2016 r. uzyskał stopień doktora nauk teologicznych na Papieskim Wydziale Teologicznym w Warszawie, na podstawie pracy poświęconej ks. Luigiemu Giussaniemu, założycielowi międzynarodowego ruchu Comunione e Liberazione. Od najmłodszych lat jest on związany z Drogą Neokatechumenalną co poniekąd przenosi się na treść recenzowanej książki, która emanuje optymizmem w stosunku do Soboru Watykańskiego II i jego korzystnych, zdaniem autora, owoców, zwłaszcza w Ameryce Łacińskiej.

Jak zaznacza ks. Campagnaro, praca powstała po części jako odpowiedź na krytykę papieża Franciszka, wynikającą z ignorancji i opacznie rozumianej posoborowej teologii latynoamerykańskiej (s. 11). Nieco bardziej dosadnie autor wyraził to w Zakończeniu pracy: "główną intencją z jaką przystąpiłem do pisania tego opracowania, było dostarczenie narzędzi, które przybliżyłyby teologię latynoamerykańską w jej bogactwie i ewangelizacyjnym zapale badaczom i wiernym Kościoła polskiego, a w konsekwencji pomogłoby im lepiej zrozumieć duszpasterskie dzieło papieża Franciszka, syna tej teologii, który wraz z objęciem tronu papieskiego ostatecznie włączył ją do powszechnej debaty teologicznej jako ważny i konieczny wkład" (s. 123). Temat, który podjął ks. Campagnaro, wydaje się być zatem słuszny, ponieważ przeciętny europejski katolik może mieć problem ze zrozumieniem charakteru i nauczania Biskupa Rzymu z obecnego pontyfikatu, tym bardziej że nawet dla wielu mieszkańców Watykanu Franciszek po wyborze na Stolicę Piotrową wydawał się być egzotyczny i wywracać świat, do którego do tej pory byli przyzwyczajeni ${ }^{1}$.

1 https://plus.dziennikpolski24.pl/do-konca-bylam-magda-od-tego-ojca-swietego/ar/ c15-14435869 [dostęp: 8 IX 2020]. 
Praca składa się ze wstępu, czterech zasadniczych rozdziałów, zakończenia, bibliografii, indeksu osobowego i indeksu rzeczowego. W rozdziale pierwszym autor przybliżył historyczny kontekst rozwoju chrześcijaństwa w obu Amerykach, począwszy od działalności konkwistadorów aż po czasy współczesne. Recenzowana praca jednak, co kilka razy podkreśla autor, w założeniu nie ma mieć charakteru stricte historyczno-opisowego, lecz także teologiczny, pastoralny. Taki też charakter mają trzy pozostałe rozdziały. Drugi w kolejności rozdział jest poświęcony rozwojowi teologii w Ameryce Łacińskiej po Soborze Watykańskim II, konferencjom biskupów z CELAM (Rada Biskupów Ameryki Łacińskiej) w latach 1955-1968 oraz wizycie papieża Pawła VI w Kolumbii, gdzie zainaugurował on jedną $\mathrm{z}$ takich konferencji i wygłosił obszerne przemówienie. Czwarty rozdział został poświęcony w całości „teologii wyzwolenia”, w tym tzw. teologii ludu. Autor charakteryzuje zasadnicze nurty tej latynoskiej wizji teologii społecznej, podając zarazem główne aspekty jej krytyki. Ostatni rozdział dotyczy współczesnych perspektyw rozwoju i znaczenia latynoskiej teologii, powstałej na zrębach teologii wyzwolenia, także w kontekście nauczania papieża Franciszka. Za podstawę bibliograficzną ks. Compagnaro przyjął kilka dokumentów Kościoła powszechnego, dokumenty CELAM, a także sporą liczbę opracowań, w tym obcojęzycznych. Praca z założenia autora ma być krótka, treściwa i dosadnie prezentująca charakterystykę teologii Ameryki Łacińskiej w celu lepszego zrozumienia przekazu duszpasterskiego papieża Franciszka.

$\mathrm{W}$ rozdziale pierwszym ks. Compagnaro słusznie wiele miejsca poświęcił objawieniom maryjnym w Guadalupe i ich wpływowi na przyspieszoną chrystianizację obu Ameryk. Jak zaznacza autor: „Jest opinią powszechnie akceptowaną dziś przez teologów i historyków w tej dziedzinie, że ewangelizacja obu Ameryk była raczej mariologiczna niż chrystologiczna" (s. 21). Kult maryjny jest jednak sam w sobie chrystocentryczny - na tym polega jego istota. Maryja w objawieniach w Guadalupe przyniosła ludziom nie tyle samą siebie, co przyniosła Chrystusa. Zapowiedź takiego stanu rzeczy jest zresztą niejako wyrażona w Jej wizerunku na słynnym obrazie - Matka Boża jest tam bowiem brzemienna, o czym świadczy jej strój, a konkretnie przepaska na sukni. Zdaję sobie sprawę $\mathrm{z}$ tego, że autor wskazuje $\mathrm{w}$ ten sposób na kult maryjny, który być może w jakiś sposób wypierał chrystologiczny i chrystocentryczny charakter chrześcijaństwa, jednak w czasie chrystianizacji (nie „maryizacji”) Ameryki Łacińskiej celem było przekazanie wiary chrześcijańskiej takiej, jaka była znana w Europie, tyle że z wyraźnie zaakcentowanym kultem maryjnym. Autor słusznie eksponuje „fenomen Guadalupe” i podaje, że szacunkowo w ciągu tylko siedmiu lat od objawień chrzest przyjęło około ośmiu milionów osób (s. 20). Kościół zyskał wtedy o wiele więcej wiernych, niż 
stracił w Europie w wyniku reformacji protestanckiej. I to kolejny element, o którym zapomniał wspomnieć autor książki - chrystianizacja obu Ameryk dokonywała się $\mathrm{w}$ cieniu reformacji, a potem kontrreformacji. Protestantyzm - niezależnie $\mathrm{w}$ jakiej formie - był też pozbawiony kultu świętych, w tym kultu maryjnego. Ten ostatni nabrał zatem zupełnie nowego wymiaru na niespotykaną dotąd skalę, mimo że miał miejsce w odległych zakątkach świata. Reformacja też de facto otworzyła drogę do laicyzacji polityki życia politycznego i społecznego w krajach, w których przewagę zyskali protestanci ${ }^{2}$, a był to proces przez kilka wieków niewidoczny w Ameryce Łacińskiej. Zaznaczył się on wyraźnie dopiero w okolicach XIX w., o czym także wspomina autor, jako jedną z przyczyn podając kasatę zakonu jezuitów, którzy działali prężnie także za oceanem. Uwzględnia zatem przyczyny laicyzacji Ameryki mające swoje źródła w Europie, choć ich kontekst był o wiele szerszy, wyraźnie polityczny, powiązany ze skutkami Rewolucji Francuskiej i okresu napoleońskiego.

Autor wyraża niezadowolenie w związku z tym, że nawracanie Indian na chrześcijaństwo miało charakter przymusowy. Wyraża to, przytaczając zwłaszcza następujące słowa P. Vanzana: "grzech pierworodny całego przedsięwzięcia tkwi w fakcie (konstantyńskim, ale nie ewangelicznym), że neutralizacja opozycji odbywała się poprzez przymusowe nawracanie Indian na chrześcijaństwo" (s. 15). Przywołuje wypowiedzi Pedro de Cordoby o zniszczeniu Indian ",na ciele i na duszy” i o tym, że nawet faraon nie uciskał tak Żydów, jak robili to osadnicy względem Indian (s. 17). Odwołuje się $\mathrm{w}$ ten sposób poniekąd do postawy papieża Jana Pawła II, który przepraszał za "grzechy" Kościoła z przeszłości, w tym przymusową chrystianizację. Należy jednak pamiętać, że tamtejsi, ówcześni „ewangelizatorzy", którzy byli na ogół uzależnieni od konkwistadorów i od polityki państw europejskich, dominujących na tych terenach, nie znali innych metod. Autor sam przytacza poszczególne bulle papieskie z XVI w., które stworzyły podatny grunt pod „kolonialny model chrześcijaństwa", ale warto dodać, że były one w istocie często odpowiedzią na ekspansywno-militarny charakter islamu, który także nakazywał nawracać siłą. Trudno zresztą wyobrazić sobie, by rekonkwista i zdobycie Grenady w 1492 r. odbyło się inaczej niż przy użyciu sił militarnych. Należy też mieć na uwadze szok, jaki przeżyli Europejczycy, widząc praktyki Indian, zwłaszcza religijne, np. składanie bogom ofiar z ludzi, nieznane w Europie od czasów antycznych. Wielu europejskich przybyszy, w tym prominentnych osób, poniosło przecież śmierć ze strony Indian $\mathrm{w}$ taki waśnie sposób. W tym kontekście stwierdzenia o „krzywdzeniu duszy

2 Dobrze zobrazował tę tematykę Adam Wielomski. Zob. A. Wielomski, Myśl polityczna Reformacji i Kontrreformacji, t. 1, Rewolucja protestancka, Radzymin 2013. 
Indian" w wyniku przymusowej chrystianizacji są dosyć polemiczne. M. Compagnro ma jednak rację, krytykując politykę niewolniczą konkwistadorów - wiązała się ona niemalże z zagładą ludności tubylczej obu Ameryk, w wyniku której, wedle różnych szacunków, wyginęło niemal 90\% rdzennej ludności.

Autor podkreśla, że jedną z zasług teologii wyzwolenia jest „dynamizm misyjny". Słusznie zaznacza, że misyjność Kościoła jest jego nieodłączną cechą. Na dowód przytacza dokumenty CELAM i kerygmatyczny charakter teologii papieża Franciszka. Z książki nie dowiemy się jednak, jakie, zwłaszcza współcześnie, zasługi na polu misyjnym posiada teologia wyzwolenia. Jeśli chodzi o rozwój katolicyzmu, trzeba przyznać, że Kościół w Ameryce Łacińskiej ponosi klęskę. Jak podkreśla autor pracy: „Obserwujemy w Europie społeczeństwo, które coraz szybciej się sekularyzuje, gdzie religia jest marginalizowana do sfery prywatnej. Poza tym Kościół Europie wydaje się być zmęczony i obciążony bogactwem, skandalami i brakiem zaangażowanych księży i świeckich" (s. 10). Problem polega jednak na tym, że Ameryka Łacińska także się laicyzuje i choć nie jest jeszcze tak laicka jak Europa, to w przyszłości prawdopodobnie podzieli jej los. W dodatku coraz prężniej rozwija się tam pentakostalizm, czyli ruch zielonoświątkowy - zjawisko to jest tam obecne od lat sześćdziesiątych XX w., czyli mniej więcej od czasu Soboru Watykańskiego II. Wedle sondażu przeprowadzonego przez Pew Research Center w 2014 r. protestanci w Ameryce Łacińskiej są bardziej religijni niż katolicy, którzy wydają się być mocno zlaicyzowani ${ }^{3}$. Wedle ustaleń Leszka Jańczuka za sukcesem zielonoświątkowców w obu Amerykach stoją osłabienie wpływów Kościoła katolickiego wskutek industrializacji i urbanizacji, atrakcyjność dla ubogich warstw społecznych, odwołanie do emocjonalnej natury człowieka oraz kultury latynoamerykańskiej ${ }^{4}$. O sukcesie protestanckich "misjonarzy” z Ameryki Północnej przesądza też to, że oferują oni pomoc $\mathrm{w}$ poprawie statusu materialnego - ich działaniom uległ już co piąty Brazylijczyk ${ }^{5}$. Można więc zadać pytanie, jakie zasługi na tym polu w Ameryce Łacińskiej posiada lansowany przez obecny pontyfikat „Kościół ubogi dla ubogich" i dlaczego ludzie miast niego, wybierają wspólnoty protestanckie i deklarowaną przez nich pomoc. Skoro autor wspomniał o skandalach w europejskim Kościele, to warto też dodać,

\footnotetext{
3 https://www.pewforum.org/2014/11/13/religion-in-latin-america [dostęp: 24 VIII 2020].

4 L. Jańczuk, Przyczyny rozwoju pentekostalizmu w Ameryce Łacińskiej, „Rocznik Teologiczny" 2016, 1, s. 123-135.

5 https://www.pch24.pl/katolicyzm-w-ameryce-poludniowej-dalej-wdefensywie,22503,i.html [dostęp: 24 VIII 2020].
} 
że wstrząsają one także tym latynoamerykańskim, zwłaszcza w Chile i w Meksyku. W tym pierwszym sytuacja była tak poważna, że cały tamtejszy episkopat kilka lat temu podał się do dymisji, a 18\% Chilijczyków to obecnie zdeklarowani ateiści. Z badań wynika też jasno, że mieszkańcy Chile laicyzują się w zawrotnym tempie i tracą zaufanie do Kościoła ${ }^{6}$, podobny proces, choć mniej intensywnie, dotyka także inne kraje Ameryki Łacińskiej, zwłaszcza Kolumbię, gdzie szczególnie młodzież laicyzuje się w bardzo szybkim tempie.

Wymieniając przyczyny rozwoju teologii wyzwolenia, autor stwierdza: „Zapóźnienie w rozwoju niektórych narodów nie polegało bowiem na spowolnionym ich rozwoju w stosunku do rozwoju innych: było tego rozwoju innych oczywistym efektem. Bogactwo jednych wzrosło i trwało dzięki nędzy drugich. [...] Ubóstwo krajów Ameryki Łacińskiej nie wynikało $\mathrm{z}$ niedoboru dóbr materialnych, ale z pewnego rodzaju niesprawiedliwości społecznej, która z chrześcijańskiego punktu widzenia jest grzechem" (s. 77-78). Nie odmawiając autorowi racji, trzeba podkreślić, że nie wykazał on konkretnej drogi duszpasterskiej będącej środkiem zaradczym na przedstawione problemy, a można polemizować z tym, czy może nim być współczesna teologia wyzwolenia. Przed pozornym podobieństwem socjalizmu do katolickiej etyki społecznej przestrzegał już Leon XIII w encyklice Rerum Novarum. Teologia wyzwolenia w jednym z nurtów przesiąknięta jest marksistowską interpretacją rzeczywistości społeczno-politycznej, akceptującą istnienie walki klas, co było nie do zaaprobowania przez żadnego z papieży, w tym przez Jana Pawła II. Jak zaznacza Rocco Buttiglione, włoski polityk niegdyś współpracujący ściśle z Janem Pawłem II, polski papież krytykował jedynie walkę klas i nieetyczne metody walki o sprawiedliwość społeczna, popierał jednak teologię "ubogiego latynosa" i był skłonny do dyskusji z wyznawcami tego ruchu komunistycznego ${ }^{7}$. Tutaj jednak także chciałbym zwrócić uwagę na pewien mankament ocenianej książki.

W trakcie lektury czasem odnosi się wrażenie, że autor próbuje „na siłę" usprawiedliwić teologię wyzwolenia, podejmując wysiłki, by ją przedstawić $\mathrm{w}$ jak najlepszym świetle i z tego powodu przeinacza lub przemilcza pewne fakty. Dla przykładu, na s. 88 wspomina o Zgromadzeniu Episkopatu Ameryki Łacińskiej w Puebli w 1979 r., które jego zdaniem nie potępiło teologii wyzwolenia, „było krokiem naprzód”, oznaczało „odzyskanie świadomości historycznej i podkreślenie znaczenia misji”.

6 https://wyborcza.pl/7,75399,24313198,chilijczycy-odchodza-od-kosciola.html?disableRedirects=true [dostęp: 24 VIII 2020].

7 https://www.niedziela.pl/artykul/106742/nd/Jan-Pawel-II-Franciszek-a-teologia [dostęp: 8 IX 2020]. 
Jednak przemówienie inauguracyjne na tym Zgromadzeniu, o czym nie wspomina ks. Compagnaro, wygłosił papież Jan Paweł II, który był tam wówczas obecny w czasie swojej pierwszej pielgrzymki do Meksyku. Ojciec Święty w dosyć ostrych słowach skrytykował wówczas teologię wyzwolenia, która w karykaturalny sposób próbuje ukazać Jezusa jako działacza politycznego i rewolucjonistę ${ }^{8}$. Papież przestrzegał przed postrzeganiem Chrystusa jako proroka, który nawołuje do przewrotu, jak też przed utożsamianiem go z rewolucjonista, a wszelkie rozważania na Jego temat powinny obejmować całą prawdę o Nim, zwłaszcza w kontekście boskości i darmowości zbawienia. Dokument z Puebli wyraził się też krytycznie na temat marksizmu i posługiwania się marksistowską analizą rzeczywistości ${ }^{9}$. Trudno zrozumieć, dlaczego autor pominął ten element i się do niego nie odniósł. W recenzowanej książce polski papież jest jak gdyby wielkim nieobecnym tego Zgromadzenia. Kilka stronnic dalej ks. Compagnaro podkreśla, że encykliki papieża-Polaka Sallicitudo rei socialis i Centesimus annus „zarysowują horyzont refleksji teologii wyzwolenia”, a są to "encykliki poświęcone sprawiedliwości społecznej i tematowi masowego ubóstwa" (s. 91). Sprawiedliwość społeczna jest ważnym elementem tych encyklik, jednak papież wyraźnie potępił w nich ideę państwa opiekuńczego i opowiedział się za trzecią droga a nie za kapitalizmem ${ }^{10}$, co raczej mija się z perspektywą teologii wyzwolenia, nawet tej współczesnej, pozbawionej zwykle naleciałości z ideologii marksistowskiej. Na tej samej stronie ks. Compagnaro przytacza też list papieża do biskupów brazylijskich z 1986 r., w którym podkreślał, że teologię wyzwolenia należy odczytywać na nowo w odniesieniu do Tradycji i nauczania społecznego Kościoła, jako koncepcję aktualną i konieczną. Z książki można wysnuć wniosek, że Jan Paweł II do teologii wyzwolenia odnosił się pozytywnie, co nie jest do końca zgodne z prawda, gdyż papież odnosił się przychylnie tylko do niektórych jej aspektów, potępiając te, które były sprzeczne z doktryną chrześcijańską. Nastrój panujący po konferencji autor interpretuje jako pozytywny, jednak na teologię wyzwolenia w tym czasie spadło wiele głosów krytyki, dochodzących z Kościoła powszechnego - niektórzy domagali się jej oficjalnego potępienia i w tym duchu Kongregacja Nauki Wiary wydała instrukcję Libertatis nuntius, odnosząc się krytycznie do jej koncepcji. Ksiądz Compagnaro podkreśla, że instrukcja potępiła zasady myśli marksistowskiej w teologii wyzwolenia

8 A. Stelmach, Teologia wyzwolenia w Ameryce Łacińskiej, w: Trzeci świat. Wybrane problemy krajów rozwijających się, red. W. Malendowski, S. Zakrzewski, Poznań 1989, s. 73.

9 D. Gardocki SJ, Teologia wyzwolenia jako odpowiedź na epokowe wyzwania czasu, Kraków 2019, s. 35, 41.

10 Jan Paweł II, encyklika Centesimus annus, nr 48. 
(s. 89), lecz należy zaznaczyć, że zasięg jej krytyki był znacznie szerszy i obejmował inne zagadnienia społeczne i teologiczne, takie jak samo pojęcie „wyzwolenia”, które w teologii katolickiej ma dotyczyć przede wszystkim wyzwolenia od niewoli grzechu, co opisano już w samym Wstępie dokumentu.

Autor podkreśla, że „teologia ludu”, z której wywodzi się Franciszek, nie uznaje marksistowskiej walki klas, a w jej miejsce stawia „,argentyńską szkołę" postrzegania ludu w perspektywy kulturowej, a nie z perspektywy terytorium czy klasy społecznej (s. 93-94). Podaje w nawiasie takie pojęcia, specyficzne dla Ameryki Łacińskiej, jak: lud, antylud, mieszanka kulturowa, lecz ich nie definiuje. Jednak odnoszę wrażenie, że autor - świadomie lub nie - celowo pominął pewne implikacje myśli społecznej papieża Franciszka. Pominął na przykład fakt, że w młodości był blisko związany z lewicującą organizacją Guardia de Hierro w Argentynie i pozostawał pod wpływem populizmu peronistycznego, choć w późniejszym okresie z nim polemizował. Ślady tej działalności widać wyraźnie w jego obecnych poglądach, a także w jego wypowiedziach. W wywiadzie udzielonym dziennikowi „La Repubblica” przyznał na przykład, że ludzie uważają go za komunistę, oceniając przy tym, że „komuniści myślą jak chrześcijanie" ${ }^{11}$. Papież zarazem wyraził pragnienie udziału ubogich i ruchów ludowych w polityce. Wokół tego właśnie zagadnienia, jego przyczyn i ewentualnych, możliwych korzyści oscyluje też recenzowana książka. Jak ocenił katolicki publicysta Tomasz Terlikowski, odnosząc się do niefortunnej wypowiedzi papieża Franciszka o komunizmie: „Nieustanne powracanie do ludu i ruchów ludowych, które mają być rzekomo lekarstwem na całe zło polityki, to pozostałość młodzieńczego zaangażowania w młodzieżówkę peronowską. Nie bez znaczenia dla tego myślenia jest także latynoskie, właściwe pewnej części Kościoła w Ameryce Łacińskiej postrzeganie komunizmu, jako ruchu szczerych, choć czasem zwiedzonych idealistów. Tego rodzaju myślenie jest oczywiście nie do zaakceptowania dla kogoś, kto doświadczył komunizmu"12. Terlikowski wielokrotnie przypominał też, że w swoim nauczaniu społecznym najczęściej cytuje papieża Jana XXIII i Pawła VI, którzy sprzeciwiali się niesprawiedliwości społecznej, jednak takie myślenie prawicowy publicysta - nawet licząc się z tym, że nazwą go heretykiem - określił jako anachroniczne: „Ojciec Święty wciąż przykłada bowiem do świata kategorie z lat 60. i 70. XX w. Świat jest dla

11 https://wiadomosci.dziennik.pl/swiat/artykuly/535269,papiez-mowia-ze-jestemkomunista-ale-to-komunisci-mysla-jak-chrzescijanie.html [dostęp: 8 IX 2020].

12 https://telewizjarepublika.pl/terlikowski-komunisci-jak-chrzescijanie-nieszczesnaforma-papieskiej-wypowiedzi,40501.html [dostęp: 8 IX 2020]. 
niego przestrzenią sporu między bogatymi a biednymi, a homilie pełne tak charakterystycznych dla Jana XXIII i Pawła VI wezwań do budowania pokoju i sprawiedliwości społecznej. Problemem jest tylko to, że od tego momentu zmienił się nie tylko świat, ale także nauczanie społeczne Kościoła". Jak zaznacza Terlikowski, Jan Paweł II i Benedykt XVI sprzeciwiali się niesprawiedliwości społecznej, ale robili to w duchu walki o godność człowieka i walki z relatywizmem, stawiali czoła wyzwaniom, przed którymi stał Kościół, w wielu zakątkach świata prześladowany, Franciszek natomiast posługuje się anarchonicznym językiem typowym dla Jana XXIII i Pawła VI ${ }^{13}$. Aby uświadomić dysonans co do źródeł inspiracji dla myśli Jana Pawła II i Franciszka, jeśli chodzi o naukę społeczną Kościoła, warto mieć na uwadze, że ten pierwszy w swoich encyklikach społecznych odwoływał się wyraźnie do poglądów Michaela Novaka, amerykańskiego ekonomisty, teologa i politologa, autora książki Duch demokratycznego kapitalizmu ${ }^{14}$, który opowiadał się za gospodarką wolnorynkową i krytykował państwo opiekuńcze.

Ojciec Święty bardzo rzadko odnosi się do wypowiedzi papieża-Polaka, niektórzy komentatorzy zwracają też uwagę, że nauka społeczna nie jest jedynym elementem Franciszka, w którym zrywa on z jego nauczaniem. "Teologię ludu”, do której przywiązany jest Franciszek, niektórzy tłumaczą wpływami populistycznej polityki Juana Peróna ${ }^{15}$. Jednocześnie autor recenzowanej książki, który w tym właśnie duchu przemilczał obecność Jana Pawła II na konferencji biskupów w Puebli, gdzie krytykował teologię wyzwolenia, jednocześnie informuje o obecności Pawła VI na II Konferencji CELAM, jaka miała miejsce w Bogocie, na której wskazywał on na potrzebę walki o sprawiedliwość społeczną, przestrzegając przy tym przed ruchami rewolucyjnymi i odwołującymi się do dialektyki marksistowskiej (s. 68-71). Andrzej Stelmach jeszcze w 1989 r. podkreślał, że teologia wyzwolenia $\mathrm{w}$ istocie wywodzi się z koncepcji chrześcijańskich, ale w swoich aksjomatach nie odwołuje się wyłącznie do "Kościoła ubogich”, wskazując na konieczność gwałtownych i radykalnych przemian, niemogących się dokonać inaczej, jak tylko poprzez rewolucję. Gustavo Gutierrez, jeden z głównych teoretyków teologii wyzwolenia, przyjmował marksistowską kategorię walki klas, a koncepcja wzajemnego braterstwa jest nie do pogodzenia z koncepcją walki o wyzwolenie w życiu społecznym ${ }^{16}$. Hiszpański jezuita i wyznawca teologii wyzwolenia

\footnotetext{
13 https://dorzeczy.pl/tygodnik/1584/Terlikowski-anachroniczny-papiez-Franciszek. html [dostęp: 24 VIII 2020].

14 Zob. M. Novak, Duch demokratycznego kapitalizmu, Poznań 2001.

15 T. Terlikowski, Rewolucja Franciszka, Warszawa 2018, s. 146.

16 A. Stelmach, op. cit., s. 70-71.
} 
Ignacio Ellacuría dostrzegał „etyczny wkład marksizmu” i podobieństwa zachodzące pomiędzy przesłaniem biblijnym a etyką Marksa, zwłaszcza gdy idzie o ucisk ubogiego człowieka ${ }^{17}$. Oskar Romero, choć był w stanie patrzeć na marksizm jako metodę analizy naukowej, gdy chodzi o porządek społeczno-ekonomiczny przestrzegał przed jego zideologizowanym opisem rzeczywistości ${ }^{18}$.

Współczesna teologia wyzwolenia dzieli się również na wiele różnych odłamów, wśród których można wymienić latynoamerykańską odmianę teologii feministycznej, która z niej wyrosła, a której przedstawicielką jest brazylijska zakonnica Ivone Gebara, karana przez Kościół na wypowiedzi na temat aborcji i feministyczną krytykę Kościoła, piętnującą obecnie także papieża Franciszka za jego domniemaną ignorancję kobiecej twórczości teologicznej, pomimo tego, iż obiecywał większą obecność kobiet $\mathrm{w}$ gremiach kościelnych ${ }^{19}$. Obecnie teologia wyzwolenia w mniejszym stopniu koncentruje się na sprawach społeczno-ekonomicznych, większą wagę przywiązując do problemów społeczno-kulturowych, co wiąże się ze zmianami zachodzącymi w życiu kulturowym, społecznym i eklezjalnym w Ameryce Łacińskiej ${ }^{20}$.

Praca ks. Matteo Compagnaro może na pewno umożliwić katolickiemu laikowi zrozumienie takich zjawisk jak teologia wyzwolenia i pewnych implikacji obecnej nauki papieża Franciszka, charakteru jego pontyfikatu, ustrzec przed zbyt powierzchowną oceną jego słów czy działań. Zdanie na temat tego, czy "teologia ludu” jest szansa, czy raczej anachronicznym przeżytkiem dla Kościoła, czytelnik może wyrobić sobie sam. Przytoczyłem tutaj wypowiedzi Tomasza Terlikowskiego, znanego z krytycznych wypowiedzi na temat Franciszka, ponieważ odnoszę wrażenie, że autor ukazuje swoje wywody zbyt jednostronnie - przemilczał kilka istotnych faktów, niesłusznie uznając je za bezprzedmiotowe, inne zaś źle zinterpretował, gwałcąc zasadę sine ira et studio. Sprawia to niestety, że książka jest w pewnym zakresie tendencyjna i mało obiektywna, choć warto zwrócić uwagę zwłaszcza na jej historiograficzny aspekt, który moim zdaniem jest jej największym atutem.

REFERENCES (BIBLIOGRAFIA)

Printed sources (Źródła drukowane)

Jan Paweł II, encyklika Centesimus annus.

17 R. Gaj, Utopia teologii wyzwolenia a Kościót Franciszka. Między dualizmem a monizmem antropologicznym, Białystok 2019, s. 280.

18 D. Pabiś CSsR, op. cit., s. 244.

19 R. Gaj, op. cit., s. 421-422.

20 D. Gardocki SJ, op. cit., s. 68. 


\section{Studies (Opracowania)}

Gaj R., Utopia teologii wyzwolenia a Kościót Franciszka. Między dualizmem a monizmem antropologicznym, Białystok 2019.

Gardocki D. SJ, Teologia wyzwolenia jako odpowiedź na epokowe wyzwania czasu, Kraków 2019.

Jańczuk L., Przyczyny rozwoju pentekostalizmu w Ameryce Łacińskiej, „Rocznik Teologiczny” 2016, 1.

Novak M., Duch demokratycznego kapitalizmu, Poznań 2001.

Stelmach A., Teologia wyzwolenia w Ameryce Łacińskiej, w: Trzeci świat. Wybrane problemy krajów rozwijajacych się, red. W. Malendowski, S. Zakrzewski, Poznań 1989.

Terlikowski T., Rewolucja Franciszka, Warszawa 2018.

Wielomski A., Myśl polityczna Reformacji i Kontrreformacji, t. I, Rewolucja protestancka, Radzymin 2013.

\section{Website (Strony internetowe)}

https://dorzeczy.pl/tygodnik/1584/Terlikowski-anachroniczny-papiez-Franciszek.html [dostęp: 24 VIII 2020].

https://plus.dziennikpolski24.pl/do-konca-bylam-magda-od-tego-ojca-swietego/ar/c1514435869 [dostęp: 8 IX 2020].

https://telewizjarepublika.pl/terlikowski-komunisci-jak-chrzescijanie-nieszczesna-formapapieskiej-wypowiedzi,40501.html [dostęp: 8 IX 2020].

https://wiadomosci.dziennik.pl/swiat/artykuly/535269,papiez-mowia-ze-jestemkomunista-ale-to-komunisci-mysla-jak-chrzescijanie.html [dostęp: 8 IX 2020].

https://www.niedziela.pl/artykul/106742/nd/Jan-Pawel-II-Franciszek-a-teologia [dostęp: 8 IX 2020].

https://www.pch24.pl/katolicyzm-w-ameryce-poludniowej-dalej-w-defensywie,22503,i. html [dostęp: 24 VIII 2020].

https://www.pewforum.org/2014/11/13/religion-in-latin-america [dostęp: 24 VIII 2020].

https://wyborcza.pl/7,75399,24313198,chilijczycy-odchodza-od-kosciola.html?disableRedirects=true [dostęp: 24 VIII 2020].

\section{NOTA O AUTORZE}

Przemysław Sołga - doktorant historii na Uniwersytecie Pedagogicznym w Krakowie, gdzie pod kierunkiem prof. Mariusza Wołosa finalizuje pracę na temat wizerunku nacjonalizmu w świetle publicystyki katolickiej Drugiej Rzeczypospolitej. Zainteresowania naukowe: historia Kościoła, historiologia, politologia religii. Publikował w takich czasopismach, jak: „Dzieje Najnowsze”, „Res Gestae”, „Historyka”, „Teologia i Człowiek”, „Sensus Historiae”. 